\title{
Escalation and Expansion of Electronics and Computer Software / Services Export Promotion Council of India (Esc): An Empirical Analysis.
}

\author{
Irfan Mumtaz K.S. MBA, NET, (PhD) \\ Research Scholar and Faculty, Al-Ameen Institute of Management Studies Bangalore-560027
}

\begin{abstract}
This is an attempt in reverence of Electronics and computer software export promotion council of India (ESC). The description of ESC espoused here is very broader, covering Electronic Hardware, Computer Software, and Information Technology Enabled Services (ITES). ESC got preferred for the analysis based on its growth which is pretty remarkable in the past two decades and also for the prospect arrangement to heighten the Indian exports.

The arrangement of this research paper is pursues. Level II aims at the importance of export promotion council of India. The growth of export promotion chosen for the current scrutiny is discussed in Level III. Facts and Inference of variables are conferring in the Level IV. The final Level projects on summary and conclusion.

Keywords: Export promotion, Growth of Electronics and computer software export promotion council, Expansion of Electronics and computer software export promotion council, Export Promotion Councils.
\end{abstract}

\section{Introduction}

Considering after 1991, Indian market has got more potential as compare with the previous decades. New economic policies hasten the economic rate in the growth and development of new India. These policies start initiating on the product quality, enhancing of cost effectiveness/reduction, promoting the exports in almost every arena of manufacturing. In this perspective, the government of India established the export promotion councils for the betterment of the exporters/ manufacturers.

This is an attempt in reverence of Electronics and computer software export promotion council of India (ESC). The description of ESC espoused here is very broader, covering Electronic Hardware, Computer Software, and Information Technology Enabled Services (ITES). ESC got preferred for the analysis based on its growth which is pretty remarkable in the past two decades and also for the prospect arrangement to heighten the Indian exports.

The arrangement of this research paper is pursues. Level II aims at the importance of export promotion council of India. The growth of export promotion chosen for the current scrutiny is discussed in Level III. Facts and Inference of variables are conferring in the Level IV. The final Level projects on summary and conclusion.

\section{Review of literature}

Aradhna Aggarwal (2005) explained EPZs open market within an economy that was dominated by distortionary trade, macro and exchange regulation and other regulatory governmental controls. And also talks on the many developing countries have been reverting to them in the early stages of their industrial development with the expectation that they provide the engine of growth to propel their economies into industrialization.

Biswanath Goldar (1989) focused on significant positive relationship between export performance and the product of total factor productivity in the determinants of export's performance in engineering products. Brian Nicholson \& Sundeep Sahay; focused on the importance of the multiplicity of institutional influences on a seemingly "rational" strategy making process and to critique the view that it is likely to progress harmoniously. It further details on the formal or informal practices to accommodate the growth of the software exports sector due to other conflicting priorities.

Dorsati Madani (1999) examined incentives offered, their costs to the country, and the type of industries and investment packages (e.g. short or long term) they attract. Incentives need to Concorde with the WTO rules and time-lines on export promotion instruments.

Rowland e. Worlu (2011) discussed on the untapped potential in overseas markets - particularly for Nigerian Exporters. The role of government is apparently relevant. Hence, this discourse assesses the effectiveness of the government support programmes to Nigerian exporters. In pursuit of this objective, data were generated from practitioners and policy makers as well as inspiration from the experience of other countries which embarked on export marketing development to crystallize the findings. 


\section{Objectives:}

$>$ To emphasize the importance of ESC.

$>$ To comprehend the growth and development of ESC.

\section{Research Methodology}

The study is purely quantitative and exploratory. This study involves the data collected from the primary as well as secondary sources. The primary data was collected primarily from Top Executives of promotion councils and Exporters, constituting the major source of data for the study. The questionnaires were designed in such a way to meet the requirements for the study. The questionnaires were consisting of all aspects of the functions and factors influencing ESC in Bangalore. Secondary data relating to ESC was collected from Reports of Ministry of Commerce, New Delhi, Office of the Electronics and Computer software export promotion council of India (ES), Bangalore and also from NASSCOM. Besides them the secondary data about ESC has been taken from published and unpublished literature to give accurate and exact statistics to contour the research.

\section{Importance of ESC:}

Electronics and Computer Software Export Promotion Council (ESC), subsidized by the government of India is India's largest Electronics and IT trade facilitation organization.

$>$ Its acts as the bridge between the government and its members (Exporters) and it also provides the juncture for the interface on export concerns.

$>$ It performs as a connection between member companies and foreign companies in the business development process.

$>$ It identifies eventual markets and purchaser for explicit products and services offered by its associates.

$>$ It organizes promotional activities like trade fairs and exhibitions, and also participation to help its associates.

$>$ It attracts foreign delegations, carries market surveys through delegations, sales and study teams and similar activities.

\section{Analysis:}

Electronics and Computer Software export promotion council of India has been divided into three main segments i.e. Electronic Hardware, Computer Software and Information Technology Enabled Services (ITES).

Electronics and Information Technology is proving to be the expansion locomotive in the current day economies of the world. The liberalized policy initiatives of the Government of India in the last decade have propelled the Indian IT industry on to a path of development and prosperity.

Table 1: Export Growth of ESC: 2000 to 2011

Rupees In Crore

\begin{tabular}{|c|c|c|c|c|c|}
\hline Year & $\begin{array}{c}\text { Electronics } \\
\text { Hardware } \\
(\mathrm{A})\end{array}$ & $\begin{array}{c}\text { Computer Software and } \\
\text { related Services } \\
(\mathrm{B})\end{array}$ & $\begin{array}{c}\text { ITES } \\
(\mathrm{C})\end{array}$ & $\begin{array}{c}\text { Total }= \\
(\mathrm{B}+\mathrm{C})\end{array}$ & $\begin{array}{c}\text { Total }= \\
(\mathrm{A}+\mathrm{B}+\mathrm{C})\end{array}$ \\
\hline $2000-01$ & 4788 & 27500 & --- & 27500 & 32288 \\
\hline $2001-02$ & 5800 & 36500 & --- & 36500 & 42300 \\
\hline $2002-03$ & 5600 & 36000 & 10500 & 46500 & 52100 \\
\hline $2003-04$ & 7700 & 41500 & 16500 & 58000 & 65700 \\
\hline $2004-05$ & 8000 & 54000 & 23300 & 77300 & 85300 \\
\hline $2005-06$ & 9625 & 75000 & 30000 & 105000 & 114625 \\
\hline $2006-07$ & 12500 & 105000 & 41000 & 146000 & 158500 \\
\hline $2007-08$ & 13200 & 125500 & 49500 & 175000 & 188200 \\
\hline $2008-09$ & 31226 & 164828 & 63006 & 227834 & 259060 \\
\hline $2009-10$ & 25900 & 173550 & 68400 & 241950 & 267850 \\
\hline $2010-11$ & 40400 & 187000 & 75500 & 262500 & 302900 \\
\hline
\end{tabular}

Source: ESC Statistical Year Book 2010-11.

Electronics and Computer Software which includes IT Enabled Services (KPO / BPO) has emerged as a very strong export sector from India with an estimated export of Rs. US\$ 302900 Crore (US\$ 66484 million) during the year 2010-11. Providing employment to over 3 million professionals, this sector has become most important sector to India's economy. Software and ITES export accounts for Rs. 262500 Crore (US\$ 57616 million) and Electronics Hardware Export is estimated to be around Rs. 40400 Crore (US\$ 8867 million). 
The effect of global melt down was felt during the year 2009-10 when export of Computer Software / Services could register small growth of $5.29 \%$ (2.95\% in US\$ terms) and Export of Electronics Hardware registered a steep decline of $17 \%$ (19.59\% in US\$ terms).

With a signs of revival in global economy, export of computer hardware and Computer Software / Services from India are back to the growth trajectory. During the year 2010-11 export of Electronics and Computer Software / Services registered a growth of 13 percent (17.75 percent in US\$ terms). Export of Electronics, Computer Software /Services sector has been maintaining an outstanding annual average growth rate of 21.45 percent (20.75 percent in US\$ terms) during the period 2005-06 to 2010-11.

Table 2: Electronics Hardware Exports in percentages

\begin{tabular}{|c|c|c|}
\hline Year & $\begin{array}{c}\text { Electronics } \\
\text { Hardware }\end{array}$ & $\begin{array}{c}\text { Increase and Decrease in Percentages of Electronics } \\
\text { Hardware }\end{array}$ \\
\hline $2000-01$ & 4788 & --- \\
\hline $2001-02$ & 5800 & 21.13 \\
\hline $2002-03$ & 5600 & -3.49 \\
\hline $2003-04$ & 7700 & 37.50 \\
\hline $2004-05$ & 8000 & 3.89 \\
\hline $2005-06$ & 9625 & 20.31 \\
\hline $2006-07$ & 12500 & 29.87 \\
\hline $2007-08$ & 13200 & 5.6 \\
\hline $2008-09$ & 31226 & 136.56 \\
\hline $2009-10$ & 25900 & -17.056 \\
\hline $2010-11$ & 40400 & 55.98 \\
\hline
\end{tabular}

Table 3: Computer Software and related Service Exports in percentages:

\begin{tabular}{|c|c|c|}
\hline Year & $\begin{array}{c}\text { Computer Software and related } \\
\text { Services }\end{array}$ & $\begin{array}{c}\text { Increase and Decrease in Percentages of } \\
\text { Computer Software and related Services }\end{array}$ \\
\hline $2000-01$ & 27500 & --- \\
\hline $2001-02$ & 36500 & 32.72 \\
\hline $2002-03$ & 36000 & -1.36 \\
\hline $2003-04$ & 41500 & 15.28 \\
\hline $2004-05$ & 54000 & 30.12 \\
\hline $2005-06$ & 75000 & 38.88 \\
\hline $2006-07$ & 105000 & 40.00 \\
\hline $2007-08$ & 125500 & 19.52 \\
\hline $2008-09$ & 164828 & 31.33 \\
\hline $2009-10$ & 173550 & 5.29 \\
\hline $2010-11$ & 187000 & 77.49 \\
\hline
\end{tabular}

Table 4: ITES Exports in Percentages

\begin{tabular}{|c|c|c|}
\hline Year & ITES & Increase and Decrease in Percentages of \\
ITES
\end{tabular}

Table 5: Computer Software and ITES Exports

\begin{tabular}{|c|c|c|c|c|}
\hline Year & $\begin{array}{l}\text { Computer Software } \\
\text { and related Services } \\
\text { (B) }\end{array}$ & $\begin{array}{l}\text { ITES } \\
\text { (C) }\end{array}$ & $\begin{array}{l}\text { Total }= \\
(B+C)\end{array}$ & $\begin{array}{l}\text { Increase in } \\
\text { Percentage }\end{array}$ \\
\hline $2000-01$ & 27500 & --- & 27500 & --- \\
\hline $2001-02$ & 36500 & --- & 36500 & 32.72 \\
\hline $2002-03$ & 36000 & 10500 & 46500 & 27.39 \\
\hline 2003-04 & 41500 & 16500 & 58000 & 24.73 \\
\hline 2004-05 & 54000 & 23300 & 77300 & 24.96 \\
\hline $2005-06$ & 75000 & 30000 & 105000 & 35.83 \\
\hline 2006-07 & 105000 & 41000 & 146000 & 39.04 \\
\hline $2007-08$ & 125500 & 49500 & 175000 & 19.86 \\
\hline
\end{tabular}




\begin{tabular}{|c|c|c|c|c|}
\hline $2008-09$ & 164828 & 63006 & 227834 & 30.19 \\
\hline $2009-10$ & 173550 & 68400 & 241950 & 6.19 \\
\hline $2010-11$ & 187000 & 75500 & 262500 & 8.49 \\
\hline
\end{tabular}

\section{Inference}

1) Electronic Hardware exports (Table: 2) were grown $21.13 \%$ in the year 2001-2002, where there was a sudden dropdown in the 2002-2003 by minus $3.49 \%$. Similar trends were followed in the next year's alternate increase and decrease in export. We could easy point out there was a drop in the hard times (Recession) by 5.6\% in 2007-08. Immediate next year i.e. 2008-09 there was a tremendous growth with increase of $136.56 \%$.

2) Computer Software exports (Table: 3 ) were pretty good in $20001-02$ by $32.72 \%$ then it was slight disturb in the next year and in 2006-07 export reached to 40\% making a blotch in the export. In 2010-11 it increased to $77.49 \%$ a remarkable boost in the sector.

3) ITES (Table: 4) as it started later as compare with the hardware and software exports, it got started up by open with $57.14 \%$ in $2003-04$ and the least was recorded in $2009-10$ by contributing $8.56 \%$.

\section{Conclusion}

India is considered as one of the finest and eminent destination for imports and exports as it provides various services to the rest of the world. And Export Promotion Councils bridge the gap between its members and with member's clients. It plays a very vital role in the Indian exports as it promotes the Manufacturer, Exporters, Importers and Suppliers. These councils strengthen the economies of many developing countries. In the last considered decade, exports of India boosted up and experienced declination too.

As we could view the changes were took place in the Electronic Hardware exports were grown $21.13 \%$ in the year 2001-2002 \& in the year 2008-09 there was a tremendous growth with increase of 136.56\%. Similar type of trend was followed by the Computer Software exports were pretty good in 20001-02 by $32.72 \%$. In 2010-11 it increased to $77.49 \%$ a remarkable boost in the sector. ITES as it got started later as compare with the hardware and software exports, it acquired the highest $57.14 \%$ in 2003-04 and the least was recorded in 2009-10 by contributing $8.56 \%$.

By seem exposed the growth and development of the export in preferred years, we could map out that there is a pleasant growth in exports and we can anticipate excellent export in the next coming years.

\section{Appendix:}

Graph 1: Export Growth of ESC

\section{Export Growth of ESC: 2000 to 2011}

Rs. In Crores



In Year

$\mathrm{B}+\mathrm{C}$ ( Electronics Hardware + Computer Software)

a $\mathrm{A}+\mathrm{B}+\mathrm{C}($ Electronics Hardware + Computer Software+ ITES)

Graph 2: Electronics Hardware Exports in percentages 


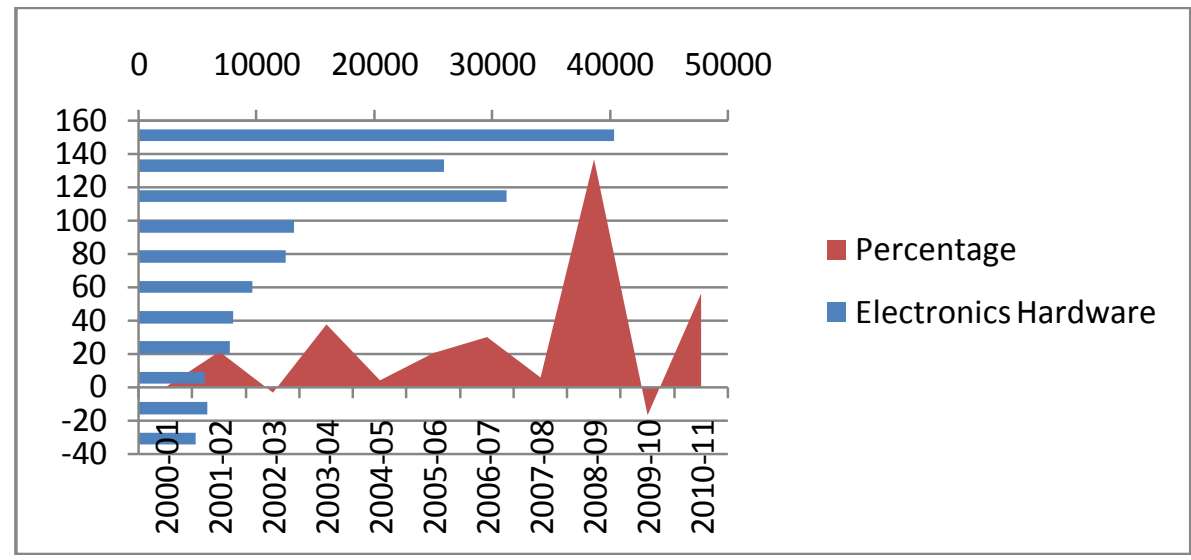

Graph 3: Computer Software and related Service Exports in percentages:

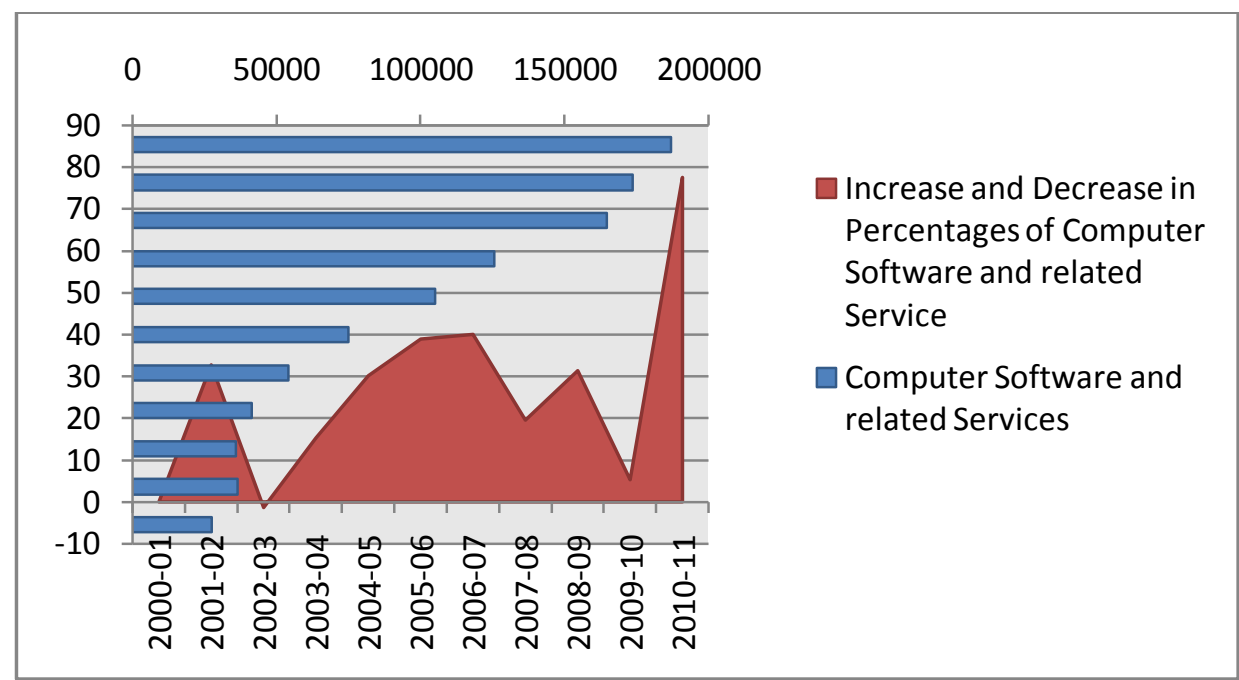

Graph 4: ITES in Percentages



Graph 5: Computer Software and ITES Exports 




[2]. Aradhna Aggarwal( 2005); Indian performance Of Export Processing Zones: A Comparative Analysis Of India, Sri Lanka And Bangladesh; Indian Council For Research On International Economic Relations; page10-15

[3]. Biswanath Goldar (1989); Determinants of India's Export Performance in Engineering Products: 1960-79

[4]. Dorsati Madani (1999); A Review of the Role and Impact of Export Processing Zones

[5]. Economic survey (2008-09); Exports and Imports and Trade Balance

[6]. Brian Nicholson \& Sundeep Sahay; Software Exports Development in Costa Rica: Contradictions and the Potential for Change, page 10-13

[7]. Economic survey (2010-11); Statistical Tables; Exports and Imports and Trade Balance; Pages 80-82,

[8]. Export promotion of consultancy and management services from India; (2006); Ministry of Commerce and Industry, Government of India, New Delhi

[9]. Felix B. Tan \& Kallaya Leewong charoen; (2010), IT for Development; Factors contributing to IT industry success in developing countries: The case of Thailand

[10]. HR. Appannaiah, PN Reddy, S. Shanthi (2005); Economics for Business, Himalaya Publishing House; Pages 435-449

[11]. Iram Khan; (2012); Impact of Foreign Direct Investment (FDI) On Indian Economy: A Sectoral Analysis;

[12]. Mats Granér; Essays on trade and productivity: Case studies of manufacturing in chile and Kenya

[13]. Rowland e. Worlu Effectiveness of government export support Programmes in nigeria: An exploratory inquiry, IJBEMR, ISSN $2229-4848$

[14]. Zala, virambhai s, (2010), a study of productivity and financial efficiency of Textile industry of India, thesis PhD, Saurashtra University. 